\title{
The Tradition of Little Man and Its Characteristics in Mikhail Zoshchenko's Sarcastic Novels
}

\author{
Yi Li ${ }^{1}$, Fan Feng ${ }^{2}$ \\ ${ }^{1}$ Xi'an International studits University, South Wenyuan Road, Xi'an Guodu Education Development Zon \\ ${ }^{2}$ Shenyang Normal University, No. 253 Huanghe North Street, Shenyang, Shenyang Normal University \\ \{Yi Li\}liyiyishu9@126.com, \{Fan Feng\}hello19820602@sina.com
}

Keywords: Mikhail Zoshchenko, little man, sarcastic novel

\begin{abstract}
Little man is one powerful device for Mikhail Zoshchenko to depict the subtle, complicated and unconscious mental or psychological activities of his characters. In his sarcastic novels, Zoshchenko uses "little man" as the central image to develop the plot and to illuminate his motif. Taking the little man character from Zoshchenko's novels as the object of research, and using his literary tradition and image setting as the breakthrough point, this paper attempts to integrate a relatively complete "Zoshchenko-style characters" pedigree through analysis of fragmented images scattered in different individual texts.
\end{abstract}

\section{INTRODUCTION}

Mikhail Zoshchenko 's sarcastic novels have portrayed a number of vivid images of the people from the bottom of the society to life in the 20s and 30s of last century, a collection of which were referred collectively by the scholars as "Zoshchenko style characters". As a satirist, Mikhail Zoshchenko has always been observing every single detail of the world just like what a log keeper in real life does. The shameless hooligan, the confused fool, the cynical businessman and the self-deceiving literati, all of whose lives could be preserved actively and vividly in Mikhail Zoshchenko's own words. The characters in Mikhail Zoshchenko's novels could be roughly divided into two kinds, namely "a little man" and "a Superfluous man", with each one of them presenting different qualities. Taking the little man character from Zoshchenko's novels as the object of research, and using his literary tradition and image setting as the breakthrough point, this paper is going to make an attempt to integrate a relatively complete "Zoshchenko style characters" pedigree through making analysis of fragmented images scattered in different individual texts.

\section{THE ORIGIN OF THE LITTLE MAN CHARACTER}

In Mikhail Zoshchenko 's early years, he was forced to drop school due to straitened circumstances of family. After that, he became a trainman working in a railway line in the Caucasus. Train could be understood as a special kind of special concept, where unrelated people of different types were "forced" to gather together at the same time, for the same purpose, and in the same place. Therefore, the narrow coach assembled the most diverse types of characters to the utmost extend. It could be said that it was lucky for Mikhail Zoshchenko to experience life as a trainman which enabled him to get access to the real, fresh diversity of human nature within the shortest time and meanwhile offered his the most convenient opportunities to do so. And after the war, he returned to Petersburg and tried 12 different jobs in street and lanes successively, and these seemingly unconnected working experiences all provided him with handy original materials for his writing. He once said proudly about his early experience, "I think every writer has to experience more, those who became a professional writer directly had made a harmful mistake, I am not exaggerating, but I am a writer with 'a resume'”. ( $\quad \mathrm{Li}, 2002)$

Stories happened on the tram, in the tube-shaped apartment, public bath, public kitchen and streets and lanes, all of which from Mikhail Zoshchenko 's novels were originated from his own 
experience in real life. As he emphasized, there was no imaginary virtual images, no fabricated stories with abstract art, all the brawls and fights as well as the descriptions of the details of those who penny wise, pound foolish or those stingy, were all picked from real life by the writer with honest attitude. As Konstantin Fedin once said: "Perhaps there's no writer who could do better than Mikhail Zoshchenko in terms of providing such rich, artistic and authentic proofs to understand certain aspects of our ethnicity." (Tomashevsky, 1990) There are certain objective reasons for the formation of populist characteristics of "Zoshchenko style characters": first of all, although he was a man of noble birth, straitened circumstances of his family made it impossible for him to get a full understanding of the cultures of the upper class, what's more, people he dealt with the most during his adolescence were those common people from the bottom of the society. Therefore, in terms of the setting of the character in literary creation, it's far more convenient for him to choose what he was familiar with rather than the aristocratic families; secondly, Mikhail Zoshchenko set ordinary people as his target audience in the first place at the beginning of his creation, and the populist setting of characters is a perfect choice for making more readers to accept his works.

\section{THE TEADITION OF LITTLE MAN IMAGE}

The survival attitude of the nobodies in real life was always being wordless and helpless, they became vulnerable and helpless because they found themselves unable to control their destiny and change the unfortunate status quo. Great concerns were given by artists from different artistic forms to those nobodies for a long time to express their thoughts about destiny, human nature and so on. The image of a little man had a long history in Russian literature history, and it's generally acknowledged that the first image of a little man appeared in Pushkin's "The Stationmaster", in which a toiled humble character was so depressed and eventually died inevitably after losing his daughter-his only sunshine in his entire life. After Pushkin, the image of a little man gradually became the focus for subsequent writers and appeared frequently in classic literature works. In Pushkin's work, the reasons why the stationmaster's destiny was tragic were the mutual exclusion of different classes and the misunder standings among people. So, the main theme of Pushkin's little was to awaken people to break the invisible barriers, and made an attempt to reconcile the deeply-hidden contradictions.

The beauty that Pushkin had hoped for was so pale and powerless facing the reality, and when it came to Nikolai Gogol, the little man was placed in an illusory situation, which was the way adopted by Nikolai Gogol on the way of self-religious morality exploring to awaken others to pay attention to those little man. "the writer (Nikolai Gogol) mystified Russian reality, and made people believe that there was a certain kind of unexplained and uncontrollable power that was manipulating people's destinies in an unseen world, and it could only make people submit rather than escape. .......Nikolai Gogol divided the mysterious and abstruse organic reality whole into something understandable realities and "unreasonable" mysticism level, from which something really important to Russia and Russian people were revealed, some psychosis and aeipathia. "(Yana, 2001)

And then, Dostoievsky emphasized those “who were bullied and insulted” little men' inner hearts, making an attempt to portray how deeply those humble "poor" ones' dignity was hurt, how much they tortured and had been davestated on the spiritual leven when there personalities were trampled,. Before Anton Chekhov, the formation of the little man image actually represented concerns were given by the writers to the major social problems such as irreconcilable contradictions among different classes, and the writers were mostly sympathetic to those little men, but from Anton Chekhov's perspective, that was changed. He thought the irreconcilable contradictions among different classes was not the only reason for teh formation of the little man image, and from then on, the little men's superficiality and shallowness became the target for the writers to mock on . when it came to the 20th century, a series of Maxim Gorky's civic novels not only gained reputation worldwide, but also pointed out that there were backwardness, ignorance and stagnation in the ordinary citizen class. Both Nikolai Gogol and Dostoievsky thought that Russ was great (Великая 
Россия), however, “Childhood”, “Among Strangers”, “My universities” became Maxim Gorky’s tool of demystification of "the great Russ". The little man image from Maxim Gorky's novel began to present some clutering type features----the ordinary citizen class, whose exsitance became the stumbling block preventing Russ from moving forward, and constantly crumbled the efforts made by the revolutionaries.

On one hand, in Russian literary works, the image of the little man was a carrier of the writers' critical consciousness, and on the other, it also was a carrier of the writers' personal emotion, such as Pushkin's compassion, Nikolai Gogol and Dostoievsky's spiritual exploration, Anton Chekhov's introspection, and Maxim Gorky's distress. It was universal that one could always sense the writers' personal emotion from those images, but Mikhail Zoshchenko was an exception. Personally I think that Mikhail Zoshchenko treated the nobodies in his works in a fair manner and in order to present objectively, the writer made a clean breast of the image of the little, and did not made any personal emotions get involved. And it was the flaws that existed and reflected by the nobodies the target for the writer's critical consciousness, and this critical attitude was transmuted into biting satire of the writer.

The little man was a generic term for one social group, and from Mikhail Zoshchenko perspective, it mostly referred to the image of bottom people from the streets and lanes. A lot of critics defined the little man appeared in Mikhail Zoshchenko's works as images of “Ordinary people", the author here, however, could not agree on that. I thought that it was way too simple and brutal to define the little man appeared in Mikhail Zoshchenko's works as images of "Ordinary people" or "sordid merchant" since both terms were strongly derogatory. Sordid merchant generally referred to those who pursued nothing but profits, and ordinary people here referred to those citizens who had gloomy mental attitude, vulgar taste and narrow mind. And also ordinary people here covered class including small businessman, petty officials, handicraftsman and average urban residents, and meanwhile it also could refer to the imperfect moral principles and ideology that possessed by this social class. So we might say that on one hand, "ordinary people" delimited the scope of a large number of people, and on the other hand, it also pointed out the state of mind of these groups of people, in other words, whoever was plebeians could be delimited to this scope. If we were going to define the images of characters from Mikhail Zoshchenko's works according to this logic, then the target for the writer to criticize was basically everyone, which was obviously not scientific. In my opinion, the purpose of the setting of the images was to present the flaws and shallowness of human nature, and for the ultimate purpose for Mikhail Zoshchenko to be ironic was to present the "habitual practice of the ordinary people", and therefore, to alert the audiences to rethink profoundly. Just as what Mikhail Zoshchenko once commented: "my theme was transformation of man, but not in the way narrated by the critics. I did not refer to the transformation of the character, but the audience, who had to cultivate his sense of resentment to the ugly and shallow side of life with the help of the satirical art.” (Li, 2002)

\section{ZOSHCHENKO'S SPECIAL QUALITY OF THE LITTLE MAN}

Just as mentioned above, the little man was not the object for Mikhail Zoshchenko to satirize but the flaws and shallowness revealed by those people who were at the bottom of the society represented by the ordinary people was the object. In the 20s and 30s from last century, there was a kind of humble, socially underprivileged and uneducated little men, who indulged themselves for momentary gratification or made a fuss and lived a boring and inefficient life because of poor personal qualities, they tended to escape when there was a problem or even still maintained the feudal superstitious ignorant attitude on those issues which were already crystal clear.

\subsection{Being self-indulgent}

What made human distinguished from animal was Self-autonomy and self-control, being indulgent was animals' nature, and the capacity of self-control made indulgence and even more serious corruption avoided. What happened to the little character in Mikhail Zoshchenko's novels was the bottomless indulgence made their strapped life even more difficult due to poor capacity of self-control. Golotov--the hero from «Buy a Hourse», a pheasant from the village of muddy pond, 
who was in desperate need of horse, bought one eventually after three years of saving, giving up smoking and drinking and a lot of twists and turns. When he got the horse, however his head was easily turned and he constantly showed off. His flaunt was in vain and his horse did not attach a lot of attention as he had ever expected, "the passersby were so indifferent" , and finally when he met someone he began to introduce his horse immediately, and he became so carried away and broke that he had to pay the debt with the horse. Throughout whole narration of the story, Mikhail Zoshchenko set a number of foreshadowings at the very beginning of the story, such as "he made a clean break from wine long time ago, and he could barely remember the taste of it”(Zochshenko,1988), this told the audience that he used to drink beforehand, but for the sake of buying a horse, he gave it up three years ago, and this also illustrated the importance of the horse for the hero; another example was the hero took off his boots for several times, getting ready to pay, but put them on again just to continue his bargaining, and this was to show he was in a serious finical straits. Maybe there was nothing wrong for people to drink a little bit when they were delighted, but to be broke just for momentary gratification constituted the proof of denial for Mikhail Zoshchenko. Another popular novel named "Lemonade" was an example to magnify the constant self-indulgence to its utmost extent: the hero was told he was definitely going to die if he drank again, and under such circumstances, the hero decided to give up drinking, he ordered a glass of lemonade instead but found that it was a kind of vodka named lemonade. When it came to this case, people with self-control would definitely refuse in the first place, the hero, however, ordered another one and tried to justify himself saying that "life had its own rules that no one could ever disobey. So, it was up to God.”(Zochshenko,1988)

These two novels were regarded as the classic representatives of Mikhail Zoshchenko. The reason why these two could stand out from the rest was Mikhail Zoshchenko pointed out sharply that "indulgent" state of mind of those who lived at the bottom of the society, and it was just this state of mind that made people corrupt and fall when they were seduced, inescapable facing their own desires. And it was always too late to awaken to truth, and to complain was the only option for those who indulged themselves for momentary gratification.

\subsection{Being mean and dilatory}

As people who lived at the bottom, the most desirable dream was to have a big fortune. On one hand, they imagined that one day they could live a good life someday, and on the other, they were still so mean and calculating and unwilling to make even the smallest sacrifices. The hero from «Economic account» could make a report on the costs of every single dish, and account the electric, water and heating charge of every single banquet he catered, and the expected joyful banquet was ended by the guests' leaving. The hero from «Economic account» was an example to illustrate how mean he was for personal profits, and actually this could illustrate how narrow-minded he was. And just because of this quality, he could only focus on his own profits and could definitely not tolerant any threat, and this quality could justify his dispised behaviours which were considered absolutely reasonable within the hero's vale judgemental system. Mikhail Zoshchenko used the superficially mean behaviors to reflect how narrow-minded the object of satire could be, and adopted customary logic to serve as a foil to show how absurd and boring the hero's conduct was.

There was another kind of character in Mikhail Zoshchenko's works, they worked in government and although they did not occupy an important position, they were so bureaucratic , dilatory and inefficient. The hero from «The one gfloshe» lost a galoshe which was not expensive when he was no a crowed bus, and it was pretty simple for him to get it back, all he needed was to go to the Lost and Found office, the hero went there back and forth, however, for a whole week to get it done. In the end, the hero gave complement to the office for its decency, which was pretty ironic here, since in all the acting system, "decency"was the only redeeming feature seemingly.

\subsection{To escape negatively}

To escape means the mentality was not accepting, when one was not able to be accustomed to new things and new environment, he would rather escape in order to stay in where they were. One part of "escape"indicated that one was going to be far away from something, and another was indicating that one was going to hide in somewhere, the nature of escape was that one was not 
couragous enough to take the responsibilities. In Mikhail Zoshchenko's early works, there were descriptions about this kind of little images who curled up themselves in the old-fashioned life and concept.

In «Poor», the audiences were told that the narrator was living in a " catastrophic" residential building in which there was only one kerosene lamp burning, and it was not until one day after the revolution that the landlady decided to install lights in those dingy rooms. Before that, everything wasmessy and dirty but was covered by the dim kerosene lamp,"the torn plasters, crawling bedbugs, sputum, cigarette butt."When the disgusting mildew was exposed under the bright light, the narrator was so shocked and ashamed in the first place, and then, after wrestling for some while, he started to clean up, "he bought some lime, tore down the plasters, swept the cobweb, fixed the sofa, panited the furniture......generally speaking, it was good, and even cozy." (Zochshenko,1988) While the narrator was enjoying the joy brought by the brightness, the landlay cut the electricity, and the reason why she would rather suffer from the darkness and smoke Throughout the whole story, there was a sharp contrast between the narrator and the landlady in terms of handling the same issue. Facing the abrupt revealing of the dirt, "I " chose to face it and handle it positively, while the landlady chose to escape from the reality.

At the very beginning of the novel, the most fashionable word was written--electrovaporization, which indicated that light was something new at that time, on one hand, it was the object representation of the new invention, and also it was a representative of the appearance of a new idea, new ideology and new civilization. The landlady, however, was curling herself up in a dark, gloomy atmosphere both in real world and her inner world, despite the appearance of light and brightness, this kind of people would escape because they were so reluctant to give up the recurring illness, the fact that the landlady escaped was actually an ignorant recalcitrance facing the new civilization and a compromise to old-fashioned corrupt.

\subsection{Being ignorant and superstitious}

There was one even more negative attitude to deal with decayed old-fashioned etiquettes besides to escape, and that was to be feodal and superstitious. Compared with escaping, being feodal and superstitious was more negative in the following ways. First of all, people escape negatively did not necessarily mean that they were exculsive to the newborn things, on the country, they had a kind of sense of identity to them, otherwise, it was not logical for the landlady in the last story to find so many excuses for her secretive behaviours since in fact she was aware of the advantages to make the room bright, but she was hindered buy her inadequate courage adn execution, therefore, she had to compromise to the old-fashioned ignorance by escaping; Being foedal and superstitious was an approval to the old-fashioned corrupt and a denial to the scientific cognition. People were fully occupied by ignorant feodal ideas which became their faith in their life, and as followers, people were allowed to make the co-exsistance of two opposite consciousness available, therefore, feodal and superstitious behavious was the result of single selection between two opposite consciousness. Secondly, the outcome of escaping negatively always exerted influence on individuals or independent groups, not others, and people who were always escapeing could be regarded as peole who would make us feel that "we were sympathetic with their sufferings, and infuriated at their indifference"'(Struve,2005), but as for being feodal and superstitious, it's not only undesirable and harmful for individuals but also others.

Mikhail Zoshchenko published his work named «The Doctor» in 1926, to which a strong rebuke was delivered among Soviet critics at that time. Olishevechy rebuked Mikhail Zoshchenko in another story that “commone ordinary philistine, .......he was digging and rummaging human's rubish and taking pleasure out of others' misforturn, he was mocking viciously at the dearkest decorative patternin that weaved Mikhail Zoshchenko’s novel.” (Dolinsky,1991)

We did not want to make any comment on this idea for the time being, but "the darkest decrotive pettern" was suffient to prove that the severity of the ultimate weakness of the little characters in «Doctor». This was a satiric novel in which a story of a man who just felt bloated which was innocuous died eventually due to superstition. He was not felling comfortable caused by gluttony at first but the professional doctor's scientific advices were questioned by the patient, "damne it, the 
priscrption was for women, ......I could not accept this advice. As for the stewed chicken, prepare that for the foreign capitalists."'(Zochshenko,1988) then, he fould a popular quack named Egoliky, who in fact, was just a wagoner, and adviced him to eat paper, and eventually killed the patient. Limited by the length of the narratives, in Mikhail Zoshchenko's short story creation, he always focused on one single target to satirize. But the story of «Doctor» was an exception since it focused on more tahn one target to satirize and that was rare. Satires could be found in the narrator's failure to tell the right from the wrong, in his state of mind to follow anyone blindly, in falsity and in the most stinging quality of superstition. The protagonist lost his right to live because of superstition, and for the same reason, his wife became an accomplice of killing her husband, the gatekeeper was in danger to become a prisoner. And all these could be interpreted as a clear manifestation of a group's ignorance, Mikhail Zoshchenko was trying to magnify the outcome of being superstitious to the utmost degree, therefore, not only the goal of being satirical was achieved, but also meanwhile, his purpose to warn those who were still got stuck in here was fulfilled.

\section{CONCLUSIONS}

Mikhail Zoshchenko had done a great job in discovering meaningful things amont those daily meaningless routines. He made his character in his novelettes from 20s to mid-30s strictly set in daily life and average people, and exposed the aeipathia existed in the average people who lived at the bottom of the society through building a character pedigree in his novels. He chose materials from daily life and confined these materials to the field of comedy creation. Unlike Shchedrin and Gogol, who would like to choose their materials from the major and significant problems of daily life, Mikhail Zoshchenko, however, would rather choose those common, boring and humble personal trifles. Life, together with its humbleness and emptiness was preserved intact, the virtues and vices, concepts and ideas remained eternally immutable and got concreted in people's barbaric and gloomy customs of 'dear Russ'. the dumb ones, the ignorant ones were the representatives of the humbles and also the manifestations of the flaws and absurdity of the reality of Soviet Union. Mikhail Zoshchenko, who deliberately collected all these things together and made them the targets of his satire, presented the deeply rooted weakness and downside of human nature in everyday life stories, without varnishing or covering anything, attempts to transform anybody or anything had never been made, the only thing he expected was that there might be some changes in some minor issues.

\section{ACKNOWLEDGEMENTS}

This paper is the phased objevtive of Xi'an International Studies University's fund, Project Number: 16XWB05.

\section{REFERENCES}

[1] Dolinsky, M., 1991. Mikhail Zoshchenko: Respectable Man, Moscow. Moscow, 2ed edition.

[2] Li, L.,2002. Study on Zoshchenko’s Novels, People’s Literature Publishing House. BeiJing, 1st edition.

[3] Struve, G., 2005. Soviet Russian Literature, Routlege. London, 1st edition.

[4] Tomashevsky, U.,1990. Memory about Mikhail Zoshchenko, Leningrad. Leningrad, 2ed edition.

[5] Yang, J.,2001. Study on Background of Russian Literature, Foreign Langnage Ressearch. 3(2), PP. 26-35.

[6] Zoshchenko, M., 1998. Novels Collection, Moscow. Moscow, 1st edition. 